\title{
Family Businesses - Problems of Accounting, Financing and Survival
}

\author{
Paweł Dec (Corresponding author) \\ Institute of Corporate Finance and Investment, Warsaw School of Economics \\ Institute of Organisation and Management in Industry "ORGMASZ", Poland \\ E-mail: paweldec@gmail.com
}

Monika Szczerbak

Institute of Organisation and Management in Industry "ORGMASZ", Poland

Received: February 28, 2017 Accepted: April 10, 2017

doi:10.5296/ber.v7i1.10843ＵRL: https://doi.org/10.5296/ber.v7i1.10843

\begin{abstract}
Paper concerns the analysis of the activities of family companies, because they represent the overwhelming majority of small and medium-sized companies in the economy. Very important, if not essential aspect of the functioning of such entities are the requirements and restrictions on their existing accounting rules. For many family businesses already just starting a business is a challenge and a breakthrough, not only in the family, but directly in everyday life. This can be compared to magnify family new baby. Hence, the authors set themselves the goal of a comprehensive approach to the issue of the functioning of family businesses and to highlight and analyze their accounting requirements in force, opportunities and sources of financing their activities, and, finally, what is equally important question of their survival. The bankruptcy of the family business is not only a loss for the economy, but it can also cause damage to individual members of the family. Thesis, which would verify the authors is that which says that these companies should be treated as partners by the government, which should not only encourage the establishment of this type of activity, but should also facilitate (or at least not hinder) doing family business.
\end{abstract}

Keywords: Family business, Accounting, Financing activities, Survival

\section{Introduction}

Activities of family requires not only the involvement of individual members of the family, and most often from different generations, but also the ability to separate the private matters 
of professional. And it is not so simple because many family businesses go bankrupt, not only in the economic area, but also such an event is often the cause of the disintegration of family ties. Hence targeted research dealing with the specificity of action of micro, small and medium-sized enterprises (many of which are family businesses, the proceeds of which are the only source of income for many households). One of the key aspects of the functioning of such entities are the requirements and restrictions on their existing accounting rules. For many micro and small business bookkeeping it is often both complicated and incomprehensible, as well as a significant cost item in the company. Therefore, the authors as the main objective set themselves critically analyze aspects of accounting in them, and the financing of family businesses. This in turn is directly related to the question of survival of such businesses, which are how valuable and important player in national economies.

\section{The Issue of Family Business}

In the world literature the concept of a family business is constantly to evaluation, which relate to economic and social changes in countries with developed market economy. You could say that the doctrine of the family enterprise has identified only a few decades ago. The most common is the approach that characterizes the family business as a company with a legal form, the capital, in whole or greater part is owned by the family, at least one family member has a leading position, and there is an intention to maintain the project in the hands of the family. Family businesses (Gallo et al, 2004) in the world operate according to the same logic and are basically similar in terms of their components, the processes occurring in them and the existing barriers and problems, as well as possible ways to solve them. The essence is the coupling of the two constituent elements - families and businesses - which determine the way of functioning, goals, cherished values and financial policy (Jeżak et al, 2004). Most decisions of family businesses, which can be found in the literature, combine the criterion of ownership and management. Both of which criteria are obligatory for them (Klimek, 2014). Sulkowski (2004) recognizes that the family business is a business entity in which the majority of the ownership structure and function of management of the entire entity remain in the hands of one family. On the other hand, according to Frishkoff (1995) family business has any form of legal capital of the company is wholly or decisive part in the hands of the family and at least one family member has a decisive influence on the management or itself holds a leading position with the intent to permanently maintain the project in the hands of the family. Budziak (2012) shows the definition of a family business focusing on the element of transfer of control of the company and the values associated with it to the next generation, "in the context of the succession of a family business is different from other types of businesses active participation of at least one person from the family in the management or the creation of a business venture in which, at least in perspective, another person of the exclusive circle of the family has the objectives: business continuity after the departure of founder by active control of the business and the implementation of the transfer of intangible assets (corporate culture), or to adapt them to the present.

Formulated definitions of family business / family business as you can see are based on different criteria. It could be broaden the definition of family companies presenting special properties: family businesses are an essential part of the assets of the family, family members 
exercise in the management, are reluctant to take the risk, carefully take strategic decisions (caution due to the threat of loss of output of all life), distrust of others - from those family (brake in the use of new ideas in business, new techniques, skills and enthusiasm of young educated personnel), form of business, family and individual, are not aimed solely at maximizing profit. On the other hand Nogalski, Bialas, Czapiewski (1993) indicate further features of the family business, "a family business is the base and the center of family life, determines the fate of family members, a family more than just a tool of power and getting money, a cult object of his successors, expressed in the attachment tradition and reap the patterns in the past, will strive to keep the company in family hands (often regardless of the methods and costs, which together implies) is the life's work of the founder."

In conclusion we can say that in principle the most popular definitions of family businesses, there are three fundamental and recurring elements: ownership (capital) from remaining in whole or in substantial part in the hands of family influence on company decisions and the intention to transfer the company to the next generation. (Więcek-Janka, 2013)

\section{The SME Sector and Family Businesses}

Small and medium-sized enterprises constitute the dominant environment in which they arise and operate family businesses. It is a natural condition resulting from two reasons: over $99 \%$ of all businesses are small and medium-sized enterprises, and the beginning of operations of most businesses is related to the generally small size of the organization. Many of these companies because of the scarcity of resources or a strategic choice not develop into large entities. Familism and the limited size of the entity, and its resources are the most characteristic features of most family businesses and significantly affect how they manage. (Jagusztyn-Krynicki, 2009) depending on the accepted definition, it is estimated that family businesses in the world account for one-third to more than $70 \%$ of all operators on the market produce between $20 \%$ and $70 \%$ of GDP and employ $27 \%$ to $70 \%$ of all employees. In Poland, family businesses are the largest group of companies. According to the Polish Agency for Enterprise Development (PARP) on the Polish market, there are about 219 thousand typical family businesses. They employ 1.3 million people. Most of them are micro, overwhelmingly, by revenues of less than 500 thousand PLN and operating on the local market.

Analysis of the structure of GDP in Poland (Table 1) demonstrates that the micro company maintain its 30\% stake in its manufacture (though noticeable slight decline in 2012 compared with 2004). On the other hand, the gross value added generated by small businesses surveyed fluctuates between around $8 \%$, which is the smallest share in the GDP structure among all groups. 
Table 1. Structure of GDP in Poland by share in the years 2004-2012

\begin{tabular}{|c|c|c|c|c|c|c|c|c|c|}
\hline \multirow[t]{3}{*}{ Year } & \multirow{3}{*}{$\begin{array}{l}\text { GDP } \\
\text { (million } \\
\text { PLN) }\end{array}$} & \multicolumn{6}{|c|}{$\begin{array}{l}\text { Gross value added produced by the } \\
\text { company (in } \% \text { ) }\end{array}$} & \multirow{3}{*}{$\begin{array}{l}\text { Gross value added } \\
\text { of other entities } \\
\text { (in } \%)\end{array}$} & \multirow{3}{*}{$\begin{array}{l}\text { Duties and } \\
\text { taxes* } \\
\text { (in \%) }\end{array}$} \\
\hline & & \multirow[t]{2}{*}{ Total } & \multicolumn{4}{|c|}{ SME } & \multirow[t]{2}{*}{ big } & & \\
\hline & & & total & micro & small & medium & & & \\
\hline 2004 & 923248 & 70,5 & 48,6 & 31,0 & 7,6 & 10,0 & 21,9 & 18,3 & 11,1 \\
\hline 2005 & 983302 & 70,3 & 47,8 & 31,5 & 7,4 & 8,9 & 22,5 & 17,8 & 11,9 \\
\hline 2006 & 1060031 & 70,7 & 47,8 & 31,0 & 7,4 & 9,3 & 22,9 & 17,2 & 12,2 \\
\hline 2007 & 1176737 & 70,8 & 47,3 & 30,4 & 7,2 & 9,8 & 23,5 & 16,7 & 12,5 \\
\hline 2008 & 1275432 & 71,1 & 47,2 & 29,9 & 7,4 & 9,9 & 23,9 & 16,5 & 12,5 \\
\hline 2009 & 1343366 & 72,3 & 48,4 & 30,4 & 7,9 & 10,1 & 23,9 & 16,5 & 11,1 \\
\hline 2010 & 1416447 & 71,6 & 47,6 & 29,6 & 7,7 & 10,4 & 24,0 & 16,5 & 11,9 \\
\hline 2011 & 1528127 & 71,8 & 47,3 & 29,4 & 7,8 & 10,1 & 24,5 & 16,1 & 12,2 \\
\hline 2012 & 1596378 & 73,0 & 48,5 & 29,7 & 7,8 & 11,0 & 24,5 & 15,6 & 11,4 \\
\hline
\end{tabular}

*Position includes: taxes and duties on imports (including excise tax), VAT - value-added tax (domestic products and foreign), excise tax on domestic products and taxes on certain types of services (eg. From games of chance and betting ), payments (contributions) made by the state budget to the budget of the European Union to the so-called. traditional own resources, i.e. customs duties, agricultural, sugar and payments (contributions) calculated on the basis of VAT, subsidies on products.

Source: (PARP, 2015)

Equally weak fall Polish micro-enterprises in the context of manufacturing gross value added compared to the EU average in terms of the individual. Because gross value added (calculated at factor cost) per one micro-enterprise in Poland is much lower than in the EU and is only 31.15. Here one should add that much better values in this area receive the remaining group of companies (small, medium, and large). Only small businesses exceed $55 \%$ of the added value of the average company in this category in the Union.

The local nature of the activity and the lack of expansion stems primarily from risk aversion and the belief that the financing of the investment should be done by means of equity. It should be noted, however, that it is the company's greatest contribution to the economic strength of family businesses, generating almost 70\% of GDP achieved by all family businesses in Poland. Their share in GDP would be considerably higher if the owners often took the challenge of expansion. This, however, requires a process of change, even through the expansion of knowledge in the field of strategic management, strategy, finance, legal and tax regulations and a number of others. The barrier to the development of family businesses is often weak economic education of owners and the inability to use the experience and knowledge of the people outside the family. Most of the family business owes its success to the adopted system of values, which is a set of rules and principles of functioning of the enterprise, as well as the desired ethical and moral attitudes of family members involved in the project. (Jeżak et al, 2004) Practice Polish family businesses and established opinions on 
the subject indicates that both the industrial, commercial and service shows a significant limitations and difficulties in doing business. Without their chances of overcoming the competitive sector in the country and abroad are minimal. Family businesses should be converted, and thoroughly revised as the transfer of the next generations. The condition of economic competitiveness and financing-related co-decide the various factors in the field of enterprise economics. In the sector of small and medium-sized enterprises to the economic health and competitiveness is influenced by the size of the assets that the firm has the ability to implement scientific and technical progress, the efficiency of enterprise resource planning, enterprise management, quality of products, the overall level of profitability of production or services, cooperative relations, the ability of promotional and advertising market image of the company. (Struzycki, 2002) In the literature described a number of barriers to the functioning of family businesses. (Popłowski, 2003) Barriers in the intellectual sphere, resulting from ignorance or lack of skill owners or managers, in particular: the tendency to treat the company as a simple system, the inability to perceive multilateral relationships and feedback, aversion to thinking perspective, focus on the present moment, the inability to recognize factors affecting the state of the company, difficulties in the division of labor as it develops. Unstable economic policy that causes uncertainty and inability to use long-term development strategy. Barrier to the sale and supply: the first is connected with shrinking markets products and services often associated with a reduction in domestic demand and difficulties to enter foreign markets; the second shows mainly congestion and freezing of financial resources in the materials. Financial barrier hindering the implementation strategy of the company and finally a key barrier to the development of family companies is the weakness of the management of the family business associated often with the inability of forming the mission and vision, building tactics and strategy, implementation of modern management tools, selection and management of people, the ability to control and assess the state of the financial, nepotism and its consequences in terms of personnel policy, dependence on business from the owner. (Stradomski, 2010)

In the vast majority of companies (94\%) there is a direct management of the company by the owner, in other cases, the owner is usually managed through other family members working in the company (5\%). Only in individual cases has been transferred to the management employed manager / managers. Allowing for the management of professional managers is rare, even in medium-sized companies $(6 \%)$, where the need for delegation of tasks and responsibilities is much greater. In these companies more often than in other management performed by other family members (16\%). More than three-quarters of medium-sized companies despite of the large size of the activity-is, however, managed directly by the owner. These findings, therefore, that the professionalization of management, as reflected in hiring professional managers from outside the family in the Polish family businesses rare. Clearly, the Polish entrepreneurs seek to maintain power in their hands, both during the formation of the business and its development, and if this is not possible, then transfer it to other family members. The need for professional management in medium-sized enterprises, employing between 50 and 249 employees, it seems obvious, and ignoring it seriously limits the development of family businesses. It must be noted that the Polish family businesses there is a strong resistance before putting power into the hands of external managers. 
According to the experts the closure of the knowledge of the outside favors conservatism in action. In their opinion, the owners of family businesses rarely come off the once chosen path and to limit the circle of decision-makers to the family causes a reduction in the flow of new ideas, a fresh perspective, which in turn results in slower growth. At one point, the company's growth is running out of family resource ideas and skills. Experts from the service sector training-consulting indicate that owners of family businesses underestimate the contacts outside the family, business networks and the benefits of belonging to the organizations business. The owners of family businesses only use external expertise for legal advice and accounting in situations where it is absolutely necessary. (PARP, 2009) The owners of family businesses should be aware of the changes, new trends and be able to respond to emerging opportunities. The speed decision making, adapting to the changing needs of consumers, the ability to use market niche lies the strength of family businesses. But to survive, they must be innovative, they must implement modern management methods

\section{Problems of Accounting in Family Businesses}

Outsourcing accounting services is not a universal solution, and the use of this modern form of organization creates a lot of opportunity to achieve an advantage over its competitors in the market (Kłos, 2009). In the world and in Western Europe to $70 \%$ of services is outsourcing basis, Poland is only 25-30\%. Research conducted by Ear (2009) show that in the field of auxiliary functions, $24 \%$ indicated an outsourcing of finance, and as much as $50 \%$ indicated it plans to apply it. As part of the outsourcing of finance about $23 \%$ is accounting. The potential of family businesses is very large, but unfortunately often business owners also have their bad habits and habits. One of them is a commitment to daily contact with the book, which has no justification. Owners should focus its attention on the development of the company and not on the analysis of invoices, receivables and liabilities. Very often it happens also that operators decide to outsource when there are problems: the auditor showed many irregularities, fiscal control, and control of Labour Inspection ended negatively, a key employee left the like. The decision to use outsourcing brings incomparably better results, it is thoughtful a strategic decision, not a tool to extinguish the fire. Institute of Chartered Accountants of England and Wales (ICAEW) published a report in which it is considering whether the accounting of small and medium-sized enterprises (SMEs) should be regulated by law. (ICAEW), document deals with the issues of costs and benefits of regulating the financial reporting of SMEs. The question it asks why the requirements for SMEs may differ from the requirements for other companies, and the findings are summarized, with which you can use in search of answers to these questions. The main thesis the report is that currently available test results are not sufficient to develop based on satisfactory basis of this policy and that there is a need to conduct further research. the requirements of financial reporting for SMEs including a significant extent imposed financial reporting family businesses vary greatly between countries and over the years. in some cases (especially when it comes to companies in which the liability of shareholders is limited) requirements for SMEs are the same as those imposed large companies in this category. in other countries, e.g. in the United States, SMEs (companies unlisted) are not subject to any rules governing financial reporting. In other cases, the regulations are an intermediate solution between the two extremes. Of 
course, the financial reporting systems are dependent on the institutional infrastructure of the country (institutions, markets, the level of technological advancement and education, the availability of alternative sources of financial reporting information.) But you have to remember also that the regulations on financial reporting impact on the environment. Where no requirements with respect to financial reporting for SMEs or are of poor quality, they develop channels of informal flow of financial information between lenders and SMEs and lenders compensate for the lack of information requirement of additional collateral in the form of higher interest rates, shorter credit period, or more accurately monitor the situation of the borrower. But there is no evidence that the individual systems are based on reasonable assumptions. Therefore, more we need to be, a comprehensive study of this issue. The report examines the issues that should be the subject of analysis and testing, prior to decisions on the rules governing financial reporting for SMEs. There are many arguments that speak for simplification of accounting solutions on issues such as derivatives, leasing, business combinations, deferred income taxes, but not a reduction in the content of financial statements. In theory and in practice, you can meet even the demand of full disclosure (Grabinski et al, 2014). Even about the data that had not previously been the subject of interest of stakeholders such as: remuneration policy, the list of bonus management, off-balance sheet data relating to the financing or transactions with related parties. Here it is important to have reported data attributes utility decision-making to the needs of interested customers. Accounting is an information system, whose main task is not only keeping records and making all sorts of statements and declarations, but also (and perhaps primarily) to provide information used in decision making (Mikulska, 2011). Research shows that the accounts run by family businesses requires improvement and development.

\section{Sources of Financing Family Businesses and Their Survival}

The main source of financing for small and medium-sized businesses (including family businesses and therefore) still own funds. Therefore, and here comes the strength of small businesses in the form of the equity, which is a kind of safety buffer distance of business by such entities. In second place among the sources of financing are loans and domestic loans (though they constitute only $17 \%$ of all sources). So low their participation proves once about mistrust of small and medium-sized entities to borrow (including, after the fear of possible consequences of their inability to repay), and two of the stringent requirements and procedures for lenders. Therefore, many players are looking for alternative sources of financing issues (such as resources from European funds).

Among the loans to small and medium-sized enterprises for many years they occupied the first place is intended to finance the operating activities (Figure 1). At the same time there has been a significant increase of more than 46 billion in December 2009 to nearly 67 billion in March 2016 year (45\% increase). In turn, investment loans increased from 34 billion zł in 2009 to 59 billion zł in 2016 (an increase by as much as 73\%). The smallest change was observed in the growth of real estate loans - 36 billion zł in December 2009 to 42 billion zł in March 2016 (an increase of 16\%).

It being added that the amount of total loans to small and medium-sized enterprises in the 
March 2016 year (nearly 188 million zl) exceeds the value of loans to large enterprises (over 147 billion PLN). The calculated coefficient of correlation between the size of loans to large companies and stakeholders from the SME sector in the period 2009-2016 amounts to 0.9181. It shows, therefore, that an increase in borrowing by large and small and medium-sized enterprises are linked with each other.

In its detailed analysis of the investment of small and medium-sized enterprises it can conclude that primarily invest them in buildings and structures, in the case of micro and small companies these expenditures account for over $53 \%$ of total expenditures. In the case of this group of companies spending on transport (and therefore undoubtedly cars), representing over $20 \%$ of total expenditure, while in the case of large companies is just over $7 \%$. On the other hand, most large companies are investing in machinery and technical equipment and tools - it is more than $51 \%$ of expenditure.

Table 2. Structure of investment expenditures by groups of fixed assets in \%

\begin{tabular}{|l|c|c|c|c|}
\hline & Buildings and structures plant, & Machinery and tools & Vehicles & Other expenses \\
\hline Micro & 53,81 & 25,53 & 20,63 & 0,03 \\
\hline Small & 53,35 & 32,61 & 13,54 & 0,51 \\
\hline Medium & 41,89 & 39,16 & 18,24 & 0,72 \\
\hline Big & 40,54 & 51,13 & 7,32 & 1,00 \\
\hline Total & 43,95 & 43,21 & 12,09 & 0,76 \\
\hline
\end{tabular}

Source: (PARP, 2015)

Increase in the volume of borrowing by small and medium-sized enterprises, however, it leads behind the increase in the value of non-performing loans. In December 2009, the volume of loans impaired amounted to nearly 17 billion PLN, while this figure in March 2016 totaled nearly 21.5 billion PLN (i.e., an increase of 26.5\%). While the increase in risk of investment loans was in the period of more than $40 \%$, and an increase in operating loans impaired amounted to $27 \%$.

In the case of large companies also saw an increase in the value of loans impaired from 8.7 billion zł in December 2009 to 10.8 billion in March 2016 year (24\% increase). You should also note the fact that the volume of loans with impairment lost for the SME sector was in March 2016 year two times higher than for large enterprises. The calculated coefficient of correlation between the size of loans to large enterprises and impaired and those from the SME sector and impaired in the period 2009-2016 amounts to 0.8179. The larger increase in the value of loans impaired for SMEs than for large companies may indicate their deteriorating economic and financial situation, which, with a limited catalog of sources of financing their activities (including relying mostly on equity) is a major threat of bankruptcy such entities. Somehow this is confirmed by data on the continuation of the business in the years since their registration. 
Table 3. Survival rates of enterprises

\begin{tabular}{|c|c|c|c|c|c|c|c|c|c|c|c|}
\hline \multirow{2}{*}{ Year } & \multirow{2}{*}{$\begin{array}{c}\text { Enterprises registered } \\
\text { in thousands }\end{array}$} & \multirow{2}{*}{$\begin{array}{l}\text { The survival rate of } \\
\text { the first year (in\%) }\end{array}$} & \multicolumn{9}{|c|}{ The survival rate in $\%$ for the year: } \\
\hline & & & 2001 & 2007 & 2008 & 2009 & 2010 & 2011 & 2012 & 2013 & 2014 \\
\hline 1995 & 374,1 & 60,0 & 32,3 & & & & & & & & \\
\hline 1996 & 607,7 & 63,3 & 38,9 & & & & & & & & \\
\hline 1997 & 485,6 & 67,9 & 41,9 & & & & & & & & \\
\hline 1998 & 453,0 & 61,7 & 44,3 & & & & & & & & \\
\hline 1999 & 337,9 & 60,2 & 52,0 & & & & & & & & \\
\hline 2000 & 293,4 & 59,0 & 59,0 & & & & & & & & \\
\hline 2001 & 209,4 & 64,5 & & 28,1 & & & & & & & \\
\hline 2002 & 176,5 & 61,5 & & 24,6 & & & & & & & \\
\hline 2003 & 176,9 & 64,4 & & 34,6 & 29,8 & & & & & & \\
\hline 2004 & 186,7 & 62,3 & & 42,1 & 35,4 & 31,4 & & & & & \\
\hline 2005 & 211,1 & 67,6 & & 51,9 & 42,0 & 36,7 & 33,1 & & & & \\
\hline 2006 & 241,6 & 66,5 & & & 55,2 & 41,0 & 36,2 & 31,3 & & & \\
\hline 2007 & 273,6 & 70,7 & & & & 54,1 & 43,5 & 37,1 & 31,8 & & \\
\hline 2008 & 294,3 & 76,4 & & & & & 58,3 & 46,8 & 38,2 & 33,0 & \\
\hline 2009 & 275,3 & 77,0 & & & & & & 59,7 & 44,0 & 35,6 & 31,4 \\
\hline 2010 & 286,2 & 77,8 & & & & & & & 54,4 & 41,9 & 35,9 \\
\hline 2011 & 274,5 & 76,6 & & & & & & & & 54,1 & 43,3 \\
\hline 2012 & 278,7 & 76,4 & & & & & & & & & 55,7 \\
\hline 2013 & 268,4 & 74,0 & & & & & & & & & \\
\hline
\end{tabular}

Source: Own study (PARP, 2004-2015, GUS, 2009-2015)

They show in fact that the survival rate of the first year of operation of new businesses that have registered their business grow steadily until 2011, when it reached $77.8 \%$ (or so enterprises registered in 2010 survived the first year). From this year is observed while the decline in this indicator and if in the years 2012-2103 he was small, it has survived in 2014 only $74 \%$ of companies that started operations in 2013. In analyzing data on survival of the company after a few years from the beginning of their operation it can be stated that generally after 5 years from the registration work still about one-third of subjects. Indeed, even among the 275,000 businesses started in 2009, in 2014 it led activity only a little more than 86,000 companies (and therefore 31.4\%). Nearly 189,000 companies ceased their activities are therefore not optimistic data. At the same time in order to obtain the whole picture about the survival of Polish enterprises from the SME sector (large enterprises are primal at all, hence the data in Table 4 can be related directly to the SME sector) it would be desirable to obtain information on the reasons for the deregistration of such entities from the database code. This would choose the right tools and take concrete actions of administrative and regulatory, which would reverse the negative trend in the survival of companies in the coming years from the time of registration. 


\section{Conclusion}

Attaching the doing family businesses is not an extraordinary thing in the economy and likewise there should be something special treatment compared to other companies. This does not change the fact, however, that regulators and public institutions should seek to facilitate such entities running a business, precisely in consideration of several generations and a commitment to run business. It should support the family businesses in the creation of a kind of bridge financing mechanisms so that in future years from the start of their operations they had the chance to continue. Small businesses are in serious financial trouble no fault of their own, and even as a result of deepening payment bottlenecks in the economy. A significant portion of small businesses not only has serious problems with repayment of borrowing or lending, it still has the same access difficult to raise such funds. Hence also a huge role in simplifying accounting principles and implementation of the most friendliest their principles of interpretation. Family businesses that go bankrupt or have only temporary liquidity problems, cause not only loss business and economical, but also cause tarnished family relationships, which may result in permanent consequences of which can be rebuild. Hence it is important to help the state and economic organizations mainly need to educate and continuous training of people working in this sector.

\section{References}

Budziak, T. (2012). Sukcesja w rodzinie biznesowej. Spojrzenie praktyczne.Warszawa: Poltext.

Frishkoff, P. A. (1995). Understanding Family Business, Austin Family Business Program, 15 April.

Gallo, M. A., Tapies, J., \& Cappuyns, K. (2004). Comparison of Family and Nonfamily Business: Financial Logic and Personal Preferences, Family Business Review, 18(4),

Grabiński, K., Kędzior, M., \& Krasodomska, J. (2014). Współczesna rachunkowość na rynkach kapitałowych. Warszawa: Difin.

GUS (2009). Warunki powstania i działania oraz perspektywy rozwojowe polskich przedsiębiorstw powstałych w latach 2003-2007. Główny Urząd Statystyczny. Warszawa.

GUS (2010). Warunki powstania i działania oraz perspektywy rozwojowe polskich przedsiębiorstw powstałych w latach 2004-2008. Główny Urząd Statystyczny. Warszawa.

GUS (2011). Warunki powstania i działania oraz perspektywy rozwojowe polskich przedsiębiorstw powstałych w latach 2005-2009. Główny Urząd Statystyczny. Warszawa.

GUS (2012).Warunki powstania i działania oraz perspektywy rozwojowe polskich przedsiębiorstw powstałych w latach 2006-2010. Główny Urząd Statystyczny. Warszawa.

GUS (2013).Warunki powstania i działania oraz perspektywy rozwojowe polskich przedsiębiorstw powstałych w latach 2007-2011. Główny Urząd Statystyczny. Warszawa.

GUS (2014). Warunki powstania i działania oraz perspektywy rozwojowe polskich 
przedsiębiorstw powstałych w latach 2008-2012. Główny Urząd Statystyczny. Warszawa.

GUS (2015).Warunki powstania i działania oraz perspektywy rozwojowe polskich przedsiębiorstw powstałych w latach 2009-2013. Główny Urząd Statystyczny. Warszawa.

ICAEW,http://www.icaew.com/ /media/corporate/files/technical/financial\%20reporting/infor mation $\% 20$ for\%20better\%20markets/sme\%20accounting\%20requirements\%20; Raport ICAEW n.t. rachunkowości MŚP https://rachunkowosc.com.pl/informacje/co-nowego-w-rachunkowosci/raport-icaew-nt.-rachu nkowosci-msp.html, 15.04.2015

Jagusztyn, Krynicki, T. (2009). Firmy rodzinne w polskiej gospodarce - szanse i wyzwania. Warszawa: PARP.

Jeżak, J., Popczyk, W., \& Winnicka-Popczyk, A. (2004). Przedsiębiorstwo rodzinne. Funkcjonowanie i rozwój. Warszawa: Difin.

Klimek J. (2014). W rodzinnej firmie. Powstanie, rozwój, zagrożenia i szanse. Warszawa: Wydawnictwo Menedżerskie PTM.

Kłos M. (2009). Outsourcing w polskich przedsiębiorstwach. Warszawa: Wydawnictwo Fachowe CeDeWu.

Mikulska, T. (2011). Outsourcing rachunkowości w firmach rodzinnych [in:] firmy rodzinne - determinanty funkcjonowania i rozwoju. Współczesne aspekty zarządzania, Przedsiębiorczość i Zarządzanie, red. Sułkowski Ł, Tom XII, Zeszyt 6, Łódź 2011.

Nogalski, B., Białas, T., \& Czapiewski, M. (1993). Zarządzanie w różnych formach własności. Gdańsk: Wydawnictwo Uniwersytetu Gdańskiego.

PARP (2004). Raport o stanie sektora małych i średnich przedsiębiorstw w Polsce w latach 2002-2003, Polska Agencja Rozwoju Przedsiębiorczości. Warszawa.

PARP (2008). Raport o stanie sektora małych i średnich przedsiębiorstw w Polsce w latach 2006-2007, Polska Agencja Rozwoju Przedsiębiorczości. Warszawa.

PARP (2009). Firmy rodzinne w polskiej gospodarce-szanse i wyzwania. Warszawa.

PARP (2015). Raport o stanie sektora małych i średnich przedsiębiorstw w Polsce w latach 2013-2014. PARP, Warszawa.

Popłowski, W. (2003). Finansowa pomoc publiczna dla małych i średnich przedsiębiorstw, Stowarzyszenie Inicjatyw Menedżerskich.Toruń: Instytut Biznesu w Kaliszu.

Stradomski, M. (2010), Finansowanie obce firm rodzinnych na rynku niedoskonałym, Warszawa: Polskie Wydawnictwo Ekonomiczne.

Strużycki, M. (2002). Zarządzanie małym i średnim przedsiębiorstwem. Uwarunkowania europejskie. Warszawa: Difin.

Sułkowski, Ł. (2004). Organizacja a rodzina. Więzi rodzinne w życiu gospodarczym Toruń: TNOiK. 


\section{Macrothink}

Business and Economic Research

ISSN 2162-4860 2017, Vol. 7, No. 1

Więcek-Janka, E. (2013) Firmy rodzinne -przedsiębiorczość długowieczna [w:] Przedsiębiorczy menedżer przedsiębiorczej organizacji. Nowoczesne tendencje w nauce oraz w praktyce organizacji i zarządzania, red. A. Marjański, Przedsiębiorczość i Zarządzanie, Tom XIV, Zeszyt 3.

\section{Copyright Disclaimer}

Copyright for this article is retained by the author(s), with first publication rights granted to the journal.

This is an open-access article distributed under the terms and conditions of the Creative Commons Attribution license (http://creativecommons.org/licenses/by/3.0/). 